\title{
Comprehensive Investigation of a Toxic Microcystis sp. (Cyanobacteria) Collected from Snow Lake (New Mexico, USA).
}

Sergei Shalygin ( $\square$ nqgood@nmsu.edu )

New Mexico State University https://orcid.org/0000-0001-8886-6666

Omar Holguin

New Mexico State University https://orcid.org/0000-0001-9957-4458

\section{Research Article}

Keywords: New Mexico, cHABs, toxins, Pacbio, Microcystis, advanced microscopy

Posted Date: December 30th, 2021

DOI: https://doi.org/10.21203/rs.3.rs-1131402/v1

License: (c) (i) This work is licensed under a Creative Commons Attribution 4.0 International License.

Read Full License 


\section{Abstract}

The toxin producing cyanobacterium Microcystis sp. was collected in the mid October 2020 from the shallow waters of Snow Lake (New Mexico, USA). This species caused a visible bloom consisting of the pale green irregular macro colonies. Mass spectral analysis of the biomass revealed the presence of 4 derivatives of microcystin in that bloom: MC-LR (in the water and biomass), MC-RR (in biomass), MC-LY (in biomass), and MC-YR (in biomass).Next-generation sequencing allowed the retrieval of two Microcystis sequences in the bloom; which are molecular benchmarks for toxic Microcystis that may be used in future monitoring studies. Light microscopy provided evidence for the taxonomic affiliation of the found morphotype as Microcystis flos-aquae (Wittrock) Kirchner. However, molecular sequencing and the present situation in cyanobacterial taxonomy prevented affiliation of our morphotype to Microcystis flosaquae, justifying following name - Microcystis sp. Confocal microscopy was used to determine the distribution of the cell content utilizing 3D stereo imaging. Emission spectra analysis identified the pigment composition and pigment distribution within the cells. SEM revealed 3D arrangement of the cells in the colonies, texture of the surface of the cells (perhaps dehydrated collapsed polysaccharides), F-layer and pili-like structures. Additionally, SEM/EDS analysis confirmed the F-layer using elemental composition analysis, which showed sulfur in the F-layer - typical element for that structure. Through the use of AFM, we analyzed the texture of the cell's surface and confirmed pili-like structures.

\section{Introduction}

Freshwater resources are rapidly declining due to pollution from wastewater, climate change, and harmful algal blooms (HABs; Anderson 2009; Adams et al. 2018; Alvarez et al. 2019). It is more of a concern in arid areas, especially those with extensive agriculture and industry (Anderson et al. 2017). In particular, HABs may cause substantial economic loss due to water anoxia, noxious water odor from geosmin, and the accumulation of toxins in food webs that can affect aquaculture (Izaguirre and Taylor 2007; Smith et al. 2010; Molot et al. 2014). Certain HABs that result from cyanobacteria are called cyanobacterial Harmful Algal Blooms (cHABs), and may occur in water bodies around the world (Carmichael 1994; Carmichael 2008). One of the major contributors to the cHABs are cyanobacterial taxa of the genus Microcystis. Worldwide, there are 13,731 occurrence records of the genus Microcystis in the GBIF (GBIF.org, 2021). According to this dataset, the first record of Microcystis is from the year 1831 and, up until 1982, records of this taxa were rather scarce (up to 20 records/year worldwide). Over the last 40 years occurrences of Microcystis spp. increased to around 500 records/year, indicating either progression of the Microcystis dominated cHABs or an increase of studies dealing with the cHABs. Most of the records were strictly botanical and were coming from temperate zones, without any analytical analysis. Not all cHABs are toxic and it is important to identify and record populations of toxic Microcystis spp. using various methods of toxin detection (Moreira et al. 2014; Briscoe et al. 2015; Blahova et al. 2021).

Samples of cHABs are complex matrices with numerous biotic and abiotic variables. Many investigations target one or two variables of a $\mathrm{CHAB}$, neglecting others and the relationships between each component. For example, many researchers interested in molecular analysis of the members of the cHABs ignore 
morphology completely (Lyra et al. 2001; Ouellette et al. 2006). In contrast to that, botanical (floristic) investigations focused on morphology exclusively (Komárek and Komárková 2002). Historically, all the taxonomy of Microcystis were based on colony shape and cell morphology observed in the light microscope (Komárek and Anagnostidis 1995; Komárek and Anagnostidis 1998), and if a classical floristic paradigm is applied, all other lines of evidence are missing. We briefly discuss different techniques for the study of cHABs below. Physiological and biochemical studies usually deal with the Flayer (AKA, EPS- extracellular polysaccharides (Hoiczyk and Baumeister 1995)) or particular aspects of photosynthesis or cell structure (Kruip et al. 1994; Weiss et al. 2019; Springstein et al. 2020), utilizing Scanning Electron Microscopy (SEM) and Transmission Electron Microscopy (TEM) techniques. Additionally, SEM and TEM are widely used in taxonomic research (Komárek and Anagnostidis 1998). Confocal microscopy is generally used in order to determine pigment composition based on emission spectra, but these studies are rare (Vítek et al. 2014; Caracciolo et al. 2019). Lastly, Atomic Force Microscopy (AFM) has been utilized in the laboratory studies investigating pili-like structures (Sure et al. 2015; Thirumurthy et al. 2020) or different aspects of cyanophages (Kuznetsov et al. 2010; Kuznetsov and McPherson 2011; Kuznetsov et al. 2013). Cyanophages are viruses that specialize in attacking cyanobacteria and might be a promising tool in cHAB management (Jiang et al. 2019). There are many "grey areas" in this topic and perhaps many undescribed cyanophages are waiting for scientific recognition and might be utilized in order to control cHABs. Pili-like structures as well as F-layer might play an important role in the cyanobacterial protection mechanism against cyanophages.

The taxonomy of Microcystis is quite problematic. There is a massive amount of molecular information from 16S rRNA sequencing as well as whole genome sequencing (Herdman and Rippka 2017). However, the type specimen of the type species for this genus is not molecularly established which makes the true phylogenetic position of Microcystis ambiguous. The best solution for this problem would be epitypification or neotypification of the type species Microcystis aeruginosa. Additionally, the threshold for the species demarcation in the phylogenetic clade of Microcystis is perhaps smaller than in other more well-established cyanobacterial taxa (Mai et al. 2018). Analysis of the secondary structure of 16S23S ITS rRNA and 23S rRNA might give additional autapomorphies for the species delineation (Johansen et al. 2017). Further metabolomics analysis with implication of Feature Based Molecular Networking may be a useful starting point for chemosystematics, which should be applied together with traditional systematics (Barbano et al. 2015; Via et al. 2018; Duperron et al. 2019).

This research aimed to comprehensively characterize toxic bloom forming cyanobacterium - Microcystis sp. collected from the alpine lake: Snow Lake (New Mexico, USA). Utilizing advanced microscopy and spectroscopy we thoroughly studied many aspects of these natural populations, such as toxin analysis, pigment characterization, elemental composition of the F-layer etc. Graphical and factoid information (16S rRNA sequences) obtained in this research might be useful in further development of the cHAB monitoring systems.

\section{Methods}


Samples of cHABs were collected from the shallow waters of Snow Lake (New Mexico, USA) on 10/8/2020. More detailed information is available on the web via CRIS (Melekhin et al. 2013) and in L. (Melekhin et al. 2019) Samples were kept on ice, in the darkness, until light microscopy observation, DNA, and toxin extraction. Samples for negatively stained TEM and pigment analysis were frozen in -80 $\mathrm{C}^{\circ}$. Samples for thin section TEM, SEM, and AFM were fixed with $2.5 \%$ solution of glutaraldehyde (several weeks storage in $4 \mathrm{C}^{\circ}$ ). Water and biomass samples for confocal analysis were kept in a glass bottle for 1 month. During this month, multiple confocal observations were recorded.

Molecular methods and phylogenetic analysis

DNA was extracted soon after sample collection using DNeasy UltraClean Microbial Kit (Cat ID: 12224-50, QIAGEN, Venlo, Netherlands). Samples were sent to MR. DNA to perform bTEFAP® PacBio Sequel analysis of the long (about 1400 bp) 16S rRNA gene region (www.mrdnalab.com, Shallowater, TX, USA). Bacterial specific primers: 27F/1492R with attached barcodes were used for amplification. Analysis utilized 10 thousand sequences per assay. The 16S rRNA gene amplification was done using a 35-cycle PCR (5 cycle used on PCR products). It used the HotStarTaq Plus Master Mix Kit (QIAGEN, USA) utilizing following steps: $94^{\circ} \mathrm{C}$ for 3 min., followed by 35 cycles of $94^{\circ} \mathrm{C}$ for $30 \mathrm{sec}, 53^{\circ} \mathrm{C}$ for $40 \mathrm{sec}$. and $72^{\circ} \mathrm{C}$ for $90 \mathrm{sec}$., after which a final elongation step at $72^{\circ} \mathrm{C}$ for $5 \mathrm{~min}$. The PCR products were observed in the $2 \%$ agarose gel, following amplification. The PCR pool was purified using Ampure PB beads (Pacific Biosciences). The SMRTbell libraries (Pacific Biosciences) were prepared following the manufacturer's guide and sequencing done at MR DNA (www.mrdnalab.com, Shallowater, TX, USA) on the PacBio Sequel following the manufacturer's guidelines. Sequences were processed using the MR DNA analysis pipeline (MR DNA, Shallowater, TX, USA). All sequences were denoised, and chimeras removed (Edgar 2016). Two Microcystis sequences were deposited into NCBI GenBank with following accession numbers: OK160994, OK160995. Megaphylogeny containing 9700 (including 2 sequences of Microcystis) sequences was performed in ARB software package (Ludwig 2004). Sequences of major representatives of nine cyanobacterial orders for the megaphylogeny were collected from Silva (Quast et al. 2012) and GenBank (Clark et al. 2016). During analysis, sequences were automatically aligned according to secondary structure of 16S rRNA molecule -SINA (Pruesse et al. 2012).Before ARB import, maximum likelihood phylogeny was calculated in the FastTreeMP software (Price et al. 2010) on XSEDE (Towns et al. 2014) based on alignment exported from SINA, with 1000 replicates.

\section{Microscopy and Spectroscopy.}

Fresh bloom material was observed on the same day as a collection using a Zeiss Axioscope light microscope with DIC optics (Zeiss, Oberkochen, Germany). Morphometric features were measured using Zeiss AxioVision LE (Zeiss, Oberkochen, Germany).

Leica TCS SP5 II confocal microscope (Leica Microsystems, Germany) was utilized for the living cells observations. Argon laser (488 nm) at 16\% intensity was used for the excitation (for the determination of 
the special pigment distribution), fluorescence emission spectra for carotenoids ranged from 510 to 605 $\mathrm{nm}$, fluorescence emission spectra for chlorophyll a ranged from 680 to $690 \mathrm{~nm}$. Sequential scan of these two spectra was implemented using HyD 4 channel in order to reduce photobleaching. Emission spectra were determined based on $x y \lambda$ scan and (Vermaas et al. 2008). Pictures showing pigment distribution were taken with following lens: $63 x / 1.4$ Oil. For the aerotopes observation different setting were used, they were: 1) reflection signal were collected at $484-493 \mathrm{~nm}$ using PMT2 channel, 2)PMT3 was used to capture all photosynthetic pigments at 582-717 nm 3) HC PL FLUOTAR 20x 0.5 DRY lens was utilized. Same laser was used for this analysis with different intensity, which was $45 \%$. Lastly, for the pigment profiling, $x y \lambda$ scan was utilized starting from $490 \mathrm{~nm}$ and ending with $700 \mathrm{~nm}$. Pigments were named according to (Vermaas et al. 2008).

Glutaraldehyde fixed cells were placed into agarose matrix inside the Eppendorf $2 \mathrm{ml}$ tubes (Mozaffari et al. 2019). Subsequently agarose blocks with the cell pellets were washed with $\mathrm{OsO}_{4}$ (Electron Microscopy Sciences, Hatfield, PA) at $2 \%$ dilution with $0.1 \mathrm{M}$ imidazole- $\mathrm{HCl}$ at $\mathrm{pH} 7.2$ inside the tubes. After that, agarose blocks were removed from the tubes and cut in the thin slices with visible osmium stained regions of the cells. Thin slices were placed in to sterile Petri dish with $\mathrm{diH}_{2} \mathrm{O}$ and were put on the shaker for 20 mins. Rinsed agarose slices were placed into $10 \mathrm{ml}$ glass vial with plastic caps for the EtOH dehydration series. Series were as follows: $50 \% \mathrm{EtOH}-20$ mins, $80 \% \mathrm{EtOH}-20$ mins, 95\% EtOH - 20 mins, absolute EtOH - 20 mins (x2). While dehydration, glass vials with the samples were places onto rotary mixer. Prior to the resin embedding, samples were rinsed with propylene oxide for 20 mins twice on the rotary mixer. Resin embedding utilized Spurr's epoxy resin (Low viscosity embedding kit, Electron Microscopy Sciences, Hatfield, PA). The rest of the procedure was followed as Robert Marc's Lab protocols (The University of UTAH). Resin blocks were cut on the Ultramicrotome in order to obtain thin sections for the TEM analysis. For the on grid negative staining (pili and cyanophages) observation, fresh grid were placed on the filtered colony and rinsed with $1 \%$ aqueous phosphotungstic acid, pH 6.5 (Vaara et al. 1984). TEM H-7650 (Hitachi High-Technologies, Tokyo, Japan) was used to observe both negative staining samples and thin section at $80 \mathrm{kV}$ (high-resolution mode). Digital camera XR 60 (AMT Corp., Woburn, MA) was utilized to capture the images.

For the SEM, dehydrated cells (as it was describe in TEM section) that were not agarose embedded were observed on Tabletop Scanning Electron Microscope, Model TM-1000 (Hitachi High-Technologies, Tokyo, Japan) without sputter coating. In this analysis, accelerating voltage was $15 \mathrm{kV}$. The rest of the SEM pictures were taken on sputter-coated material utilizing Hitachi S-3400N II (Hitachi High-Technologies, Tokyo, Japan) with the following acceleration voltage - $10 \mathrm{kV}$. Secondary electron detector was used. Sputter coating was done using Pt/Au source. Energy-dispersive X-ray spectroscopy - EDS (Noran System Six 300, Thermo Electron Corp., Madison, WI) was used to determine elemental composition of the surface of the colony (F-layer). Acceleration voltage also was $10 \mathrm{kV}$. In order to compare cyanobacterial EPS with chondroitin sulfate, small portion of a Turkey's ligament was dehydrated with absolute EtOH analyzed using EDS. 
Prior AFM scanning, glutaraldehyde fixed cells were dried out on the cover slip in the room temperature. To acquire AFM images of the pili and cell surfaces, Bruker Dimension Fast Scan (Germany) was utilized with RTESPA probe (part \#: MPP-11120-10) on the tapping mode. Amplitude error and Height sensors were implemented. Bruker NanoScope Analysis software v1.51 was used for the editing of the obtained images

\section{Toxin's analysis}

Lake water $(600 \mathrm{ml})$ was filtered through Extract-Clean ${ }^{\mathrm{TM}}$ SPE C18-HC cartridge (part no. 255350/5122524, Deerfield, IL, USA) for the released toxins, $200 \mathrm{ml}$ of lake water was filtered through the paper filter for the toxins remained in the biomass. Acetonitrile $\left(\mathrm{H}_{2} \mathrm{O}: \mathrm{ACN} / 20 \%: 80 \%, 2 \mathrm{ml}\right)$ was used for the toxin extraction. Multiple Reaction Monitoring (MRM) was implemented for high sensitive detection of the toxins as described in (Degryse et al. 2017). Standard ACQUITY ${ }^{T M}$ UPLC (Waters ${ }^{\text {TM }}$ corporation, Milford, MA, USA) system together with MICROMASS Quattro Ultima (Waters ${ }^{T M}$ corporation, Manchester, UK) was used in this analysis. Standards for following microcystins: LR, LY, RR were purchased from SigmaAldrich (St. Louis, MO, USA). Quantification of the toxins were based on standard curves. Initial quantification analysis was carried on in QuanLynx 4.1 (Waters ${ }^{\mathrm{TM}}$ corporation, Milford, MA, USA) where areas on the peak were estimated. The rest of analysis including the generation of a standard curves was done in Excel 2021 (Microsoft Corporation).

Lipophilic pigments analysis with HPLC-MS/MS

Prior pigment's extraction, $300 \mathrm{ml}$ of the lake water was filtered on the paper filter using vacuum pump. Filters with captured biomass were cut with scissors, extraction was held according (Juin et al. 2015) utilizing $2 \mathrm{ml}$ of HPLC grade EtOH (MDL \#: MFCD00003568, Thermo Fisher Scientific Inc., Waltham, Massachusetts, U.S). Pigment analysis was performed on Waters Alliance 2695 HPLC (Waters ${ }^{\mathrm{TM}}$ corporation, Milford, MA, USA) coupled with MICROMASS Q-Tof Ultima ${ }^{\mathrm{TM}}$ ESI (Waters $^{\mathrm{TM}}$ corporation, Manchester, UK). Positive mode MS ${ }^{\mathrm{E}}$ method described in (Juin et al. 2015) was adapted to HPLC/Q-Tof Ultima. LC separation was performed on Beta ${ }^{\text {TM }}$ C18 HPLC Column (part no. 70105-152130). Modified gradient steps are given in Table S1. Detailed LC-PDA-MS ${ }^{2}$ parameters are presented in Table S2. Experimental data was acquired with MassLynx software version 4.0 (Waters ${ }^{\mathrm{TM}}$ corporation, Milford, MA, USA). Following masses: 382.2 and 742.4 were excluded from the analysis as a carryover artefacts. Daughter ion masses used as a criterion used to switch to $\mathrm{MS}^{2}$ are given in Table S3. MassLynx software version 4.1 was used for pigment identification using daughter ions (Juin et al. 2015)and reference UV absorption spectra (Clementson and Wojtasiewicz 2019; Lopes et al. 2020). Additionally, reserpine (cat. \# 83580, Sigma-Aldrich, St. Louis, MO, US) was used for the Lock Mass.

\section{Graphical design}

All graphical elements were post-produced in Adobe Photoshop 2021 and Illustrator2021 (Adobe Systems Inc., San Jose, California, USA). For Figures 5B, D super resolution function in Adobe Photoshop 2021 
was applied. For Fig. S4 red/green stereo channels were overlaid in Adobe Photoshop 2021. All Fast Fourier Transform (FFT) were made in FIJI 1.53f (Schindelin et al. 2012).

\section{Results And Discussion}

\section{Morphological description of the bloom and bloom forming cyanobacteria}

Clearly visible cHAB was observed in the shallow part of the Snow Lake in the fall season of 2020. In contrast to our morphological observation, CyANapp designed by EPA predicted a wider distribution of the bloom within the lake (Fig. S1). CyANapp estimation is based on calculated reflectance near $681 \mathrm{~nm}$, called Cl index (Schaeffer et al. 2018; Mishra et al. 2021). The bloom occurred in the form of the irregular pale green clusters of the colonies close to the shore. They seemed to be in the water column all the way to the bottom in the shallow waters (up to 1 meter deep). The bloom collected on 10/8/2020 appeared significantly different to the summer collection (8/1/2020), which looked healthier. Below freezing night air temperatures may have affected colony growth in the fall. Light microscope observation revealed that 3 different species of cyanobacteria co-occurred in the cHAB sample: Microcystis flos-aquae (Wittrock) Kirchner (Fig. 1), Aphanizomenon flos-aquae Ralfs ex Bornet et Flahault, and Dolichospermum sp. Representatives of other taxonomic groups of algae were not seen in that particular water sample. However, many amoebas, flagellates, and bacteria occurred. Based on the colony shape, coccoid cyanobacterium observed in the bloom sample was identified as Microcystis flos-aquae (Wittrock) Kirchner (Fig. 1A, B). Further microscopic and phylogenetic investigations were not able to confirm this affiliation giving only genus epithet - Microcystis sp. Reason for that is the lack of the type specimen sequence of Microcystis flos-aquae (Wittrock) Kirchner. DIC imaging of the colonies (Fig. 1B) showed that the majority of the cell had aerotopes (dark regions within the cells). Aerotopes appear in this configuration since gas sharply scatters the light making aerotopes rigid and dark. Some cells did not have aerotopes (upper right corner on Fig. 1B). Figure 1B depicts an individual flagellate with an obviously ingested individual Microcystis cell. This suggests bioaccumulation of the toxins in the food web, which will be the subject of future research.

\section{Toxins found in the bloom sample}

LC/MS MRM analysis detected the presences of 4 derivatives of microcystin in the biomass sample collected from Snow Lake (Fig. 2). Microcystin - LR, - RR, - LY, and -YR were found in the biomass extract. For the first 3 microcystins we had standards (Fig. 2) confirming appropriate mass transitions (995.6 $\rightarrow$ $135.1,520 \rightarrow 135.1,1002.7 \rightarrow 135.1)$ in appropriate retention time. Additionally, microcystin-LR was found in water samples with the following concentration $0.3 \mu \mathrm{g} / \mathrm{L}$, which is substantially lower than EPA thresholds for the total microcystins. Even though the CHAB consisted of several species, we assume that Microcystis spp. mostly contributed to toxin production. Considering the oligotrophic nature of Snow Lake (Low $\mathrm{N}$ and $\mathrm{P}$, data is not shown) it was surprising to detect such a vivid $\mathrm{cHAB}$ with toxins released into the water column. With climate change and extensive agricultural practice in New Mexico and the 
USA in general, monitoring various water bodies applying analytical methods (HPLC-MS/MS, MRMs etc.) is crucially important.

\section{Phylogenetic analysis on the major taxa in the bloom}

Phylogenetic analysis of the 16S rRNA gene amplified from the bloom biomass found that two found cyanobacterial sequences clustered within the conventional "Microcystis" clade (Fig. 3, Fig. S2). Even though this clade contained 752 sequences that were identified as Microcystis, none of these sequences were sequences of the type specimen, Microcystis aeruginosa. The type species of the genus Microcystis aeruginosa was described from Weißenfels, Germany (near Leipzig, in stagnant water). In order to determine whether or not our Microcystis flos-aquae (based on morphological observation) belonged to the true Microcystis clade, epityfication of type specimen or a new type of Microcystis aeruginosa should be established. So far, there are at least two different clades on our phylogenetic tree including sequences with Microcystis affiliation. Epitypification/neotypification especially for toxic and potentially toxic taxa of cyanobacteria are quite important since many cyanobacterial species express cryptic characteristics (same morphology, different genotype). Epitypification/neotypification will label the lineages with hazardous strains which are going to be highly valuable during next-generation monitoring studies. So far, only a few "old" toxic cyanobacteria have been established correctly based on the Code (Turland et al. 2018).

Advanced microscopic and spectroscopic analyses of the Microcystis sp.

Confocal Microscopy (CM) was used in order to determine pigment distribution within the living cells of Microcystis sp. and to observe the shape of the cells (Fig. 4, Fig. S3,4). Confocal analysis of the emission spectrum showed that carotenoids were localized in the same place as chlorophylls, which is logical based on the configurations of the photosynthesis apparatus (Vermaas et al. 2008). In general, pigments that were associated with thylakoids were distributed irregularly within the cells. Basically, Microcystis sp. cells were mostly packed with two different types of matter: thylakoids (yellow color on Fig. 4) and aerotopes (concave areas/black in Fig. 4, and Fig. S4). Reflecting channel imaging used in CM (both stereo 3D and regular) confirmed that (Fig. S5A,B). Green channel (emission at 500-700 nm) showed pigments within the cells, and red reflecting channel (excitation/reflection close to $490 \mathrm{~nm}$ ) showed aerotopes (SFig. 5A,B). Aerotopes containing gas were not emitting any light, they reflected the laser. Additionally, we obtained spectrometric data showing different pigments (Fig. 4). There were chlorophyll a, phycocyanin (PC), allophycocyanin (APC), and allophycocyanin B (APC-B). Moreover, HPLC-MS/MS (plus UV-vis) analysis have detected several lipophilic pigments in the bloom sample: chlorophyll $a$ in a radical form, zeaxanthin, fucoxanthin, and dinoxanthin. Partly Chlorophyll $a$ and zeaxanthin came mostly from cyanobacteria. Fucoxanthin and dinoxanthin are more typical for other taxonomic groups of algae such as dinophyceae indicating heterogeneity of the algal species composition, which was not detected in taxonomic analysis. Lastly, "true" shapes of the cells and distribution of the cell content was determined using stereo z-stalk image (Fig. S4). Cells were spherical or hemispherical after division. 
These features are quite important in systematics and will be used if these Microcystis populations are a new taxon.

TEM was used to investigate thylakoid arrangement. As before, thylakoids were found to be irregular (Fig. $5 \mathrm{~A})$. Thylakoid membranes were entangled together with aerotopes as was observed in CM. In some cases, thylakoids surrounded groups of the aerotopes, sometimes membranes were around a single aerotope. Our thin section TEM imaging was able to resolve the structure of a cell wall (Fig. 5B). Cell membrane, peptidoglycan cell wall, outer membrane, and F-layer (aka extracellular polysaccharides EPS) were clearly recognizable. Negative staining TEM showed presence of pili-like structures (Fig. 5C), which are typical for some Microcystis spp. (Vaara 1982; Vaara et al. 1984; Stanier (Cohen-Bazire) 1988; Bhaya et al. 1999; Yoshihara et al. 2001; Schuergers and Wilde 2015). Measurements for the width of the pili were (10)16-30 (40) $\mathrm{nm}$ with the maximum width around $10 \mathrm{~nm}$. Some research suggested that two or more pili may stick to each other (Sure et al. 2015). This and microscopy artifacts may potentially explain such a range of our measurements. In general, observed pili were rather short (Vaara et al. 1984), under $1 \mu \mathrm{m}$. Functions of the pili-like structures in cyanobacteria are various and are still not fully understood (Bhaya et al. 1999). We observed pili as a "fence" that prevents cyanophages from attacking the cells. Further experiments with wild type and pililess mutants of Microcystis together with cyanophages may shed light on this unanswered question. FFT on the pili images was used in the attempt to detect a structure of a helical protein (Fig. S6D). There were only typical Airy disk patterns without signs of a protein subunit. Additionally, we linearly and radially spread (in Photoshop) 1 pixel wide portion of edge of the individual pilus in order to enhance protein structure on FFT. None of these modifications revealed protein structure. Most likely, the resolution of the microscope was not great enough to allow observation of that structure. Colonies observed on the grids (negative staining, no thin section) were surrounded by many different cyanophages with the capsid size between 125 and $190 \mathrm{~nm}$ (Fig. 5D). Taxonomically they belonged to 2 different families: Myoviridae and Podoviridae (Martin and Kokjohn 1999), the most abundant was the latter. Capsid measurement between our morphotype and the newly observed representative of Podoviridae with capsid diameter of $120 \mathrm{~nm}$ were the closest (Watkins et al. 2014). Most of the cyanophages were pushed away from the cells by pili and F-layer (Fig. S6A,B,C). Sometimes narrow spaces between the cells contained cyanophages in close contact (Fig. S6B). It seems that the pili and F-layer effectively protected cells against cyanophages. This was corroborated by the fact that none of the cells of Microcystis sp. were infected with cyanophages or caption of images was before regeneration and assembly of the cyanophages within the cells. Literature on cyanophages is rather scarce (Sullivan et al. 2003; Kuznetsov et al. 2012; Yeo and Gin 2013; Jiang et al. 2019; Zborowsky and Lindell 2019; Jaskulska and Mankiewicz-Boczek 2020), and we hope that our observation will encourage microbiologists to pay more attention to this aspect of the cyanobacterial life cycle. Additionally, we hope that microbiologists and virologists will collaborate more often in order to elucidate questions related to cyanobacteria-cyanophage interactions. 
Microscopic colonies observed with SEM (Fig. 6A) resemble the typical morphology of Microcystis flosaquae. The same identification was made after colonies were observed in the light microscope (Fig. 1). It is important to mention that edge of the colony (Fig. 6A, near bottom) was thinner compared with the middle part, in other words the edge of the colony had fewer layers of overlapping cells in 3 dimensional space. The low magnification of the colony expressed a preparation artefact, in the form of random cracks within the colony. The reason for that is the dehydration procedure as well as drying. Individual cells within the colonies were less affected by SEM artefacts (Fig. 6B). Individual cells inside the colonies formed an almost regular pattern expressed as a 3D network of the cells away from each other by the same distance (Fig. 6B). All the cells were connected with each other by slimy strings with star like arrangement, they are apparently drying artefacts consisting of shranked F-layers collapsed on the pililike structures (Fig. 6C,D; Fig. S7). The trace of the F-layers was detected by EDS technique (Fig. S8) illustrating random distribution of sulfur (typical chemical element for the cyanobacterial F-layer) on the surface of the colonies. To further confirm our finding we compared the EDS spectrum of the F-layer of Microcystis sp. with chondroitin sulfate, which is similar to cyanobacterial F-layer by chemical structure sulfated glycosaminoglycan. Similar elements and relative abundance of the peaks was observed in comparative EDS analysis supporting our original assumption (Fig. S9). Research related to cyanobacterial F-layers (EPS) is of interest to many investigators and there are targeted studies trying to answer them (Li et al. 2013; Lilledahl and Stokke 2015; Tan et al. 2020). In our research, we attempted to detect the F-layer in our strain using different techniques and were successful. Figs. $6 \mathrm{C}$ and $\mathrm{D}$ shows pililike structures, the following width of 25-125 nm, this is larger than measurements based on TEM and AFM. These discrepancies might be explained by the fact that spotter coating added some width to the structure. Moreover, dehydrated F-layer collapsed on the pili could have contributed to the thicker surface of pili. Additionally, Fig. S7 confirmed the presence of many cyanophages in the sample. Lastly, SEM revealed the texture of the cell surface, which appeared to have a bumpy texture (not smooth, as it appears in the light microscope).

AFM showed a collapsed and dehydrated F-layer, which was connecting the cells (Fig. 7). Preparation of the specimen (fixation, dehydration) did not allow us to resolve individual polysaccharides chains. However, FFT techniques showed structures similar to the polysaccharides chains (Fig. S10C, D). Fractal elements were detected by AFM: high-resolution images of the surface of the cells looked almost identical to the cell arranged in the colony expressing the same level of complexity (Fig. 11). AFM confirmed the presence of pili-like structures (Fig. 8). According to AFM, pili-like structures were in the following range (5)6-15(17) $\mathrm{nm}$. That is the smallest across the different types of microscopy we used. This may be explained by the fact that AFM measures height in contrast to TEM and SEM. Another explanation would be that pili might be submerged in debris inside the sample.

In conclusion, we establish a phylogenetic benchmark for a toxic population of Microcystis sp. from an alpine lake (Snow Lake) in New Mexico (USA). Additionally, we explored various aspects of this population utilizing different techniques. This information is important for the future monitoring of the cHABs. 


\section{Declarations}

\section{FUNDING}

FY20-21 NM WRRI Student Water Research Grant (account number: NMWRRI-SG-2020) funded this research.

\section{CONFLICTS OF INTERES}

The authors declare that they have no conflict of interest.

\section{AVAILABILITY OF DATA AND MATERIAL}

16S rRNA sequences of the Microcystis spp. are available in NCBI: OK160994, OK160995. Data matrix for the phylogeny is available in supplementary information.

\section{AUTHOR CONTRIBUTIONS}

Authors contributed equally.

\section{ETHICS APPROVAL}

None

\section{CONSENT TO PARTICIPATE}

None

\section{CONSENT FOR PUBLICATION}

None

\section{ACKNOWLEDGEMENTS}

Large thanks to Dr. Peter Cooke, who taught senior author basics of presented microscopic techniques. He also gave many practical suggestions that improved manuscript substantially. Thanks Dr. Tanner Schaub for the graduate tuition fellowship. Big appreciation to Cory B. Gargas for the English editing.

\section{References}

1. Adams CM, Larkin SL, Hoagland P, Sancewich B (2018) Assessing the economic consequences of Harmful Algal Blooms. In: Harmful Algal Blooms. Wiley, pp 337-354

2. Alvarez S, Lupi F, Solís D, Thomas M (2019) Valuing provision scenarios of coastal ecosystem services: The case of boat ramp closures due to Harmful Algae Blooms in Florida. Water 11:1250 . https://doi.org/10.3390/w11061250 
3. Anderson DM (2009) Approaches to monitoring, control and management of harmful algal blooms (HABs). Ocean Coast Manag 52:342-347 . https://doi.org/10.1016/j.ocecoaman.2009.04.006

4. Anderson DM, Boerlage SFE, Dixon MB (2017) Harmful Algal Blooms (HABs) and desalination: a guide to impacts, monitoring and management. Paris:UNESCO

5. Barbano D, Diaz R, Zhang L, Sandrin T, Gerken H, Dempster T (2015) Rapid characterization of microalgae and microalgae mixtures using matrix-assisted laser desorption ionization time-of-flight mass spectrometry (MALDI-TOF MS). PLoS One 10:1-13 .

https://doi.org/10.1371/journal.pone.0135337

6. Bhaya D, Watanabe N, Ogawa T, Grossman AR (1999) The role of an alternative sigma factor in motility and pilus formation in the cyanobacterium Synechocystis sp. strain PCC6803. Proc Natl Acad Sci USA 96:3188-3193 . https://doi.org/10.1073/pnas.96.6.3188

7. Blahova L, Sehnal L, Lepsova-Skacelova O, Szmucova V, Babica P, Hilscherova K, Teikari J, Sivonen $K$, Blaha L (2021) Occurrence of cylindrospermopsin, anatoxin-a and their homologs in the southern Czech Republic - Taxonomical, analytical, and molecular approaches. Harmful Algae 108:102101 . https://doi.org/10.1016/j.hal.2021.102101

8. Briscoe JL, Cho SY, Brener I (2015) Part-per-trillion level detection of microcystin-LR using a periodic nanostructure. IEEE Sens J 15:1366-1371 . https://doi.org/10.1109/JSEN.2014.2359881

9. Caracciolo AB, Dejana L, Fajardo C, Grenni P, Martin M, Mengs G, Sánchez-Fortún S, Lettieri T, Saccà ML, Medlin LK (2019) A new fluorescent oligonucleotide probe for in-situ identification of Microcystisaeruginosa in freshwater. Microchem J 148:503-513. https://doi.org/10.1016/j.microc.2019.05.017

10. Carmichael WW (2008) A world overview - One-hundred-twenty-seven years of research on toxic cyanobacteria - Where do we go from here? Adv Exp Med Biol 619:104-125. https://doi.org/10.1007/978-0-387-75865-7_4

11. Carmichael WW (1994) The Toxins of Cyanobacteria. Sci Am 270:78-86 . https://doi.org/10.1038/scientificamerican0194-78

12. Clark K, Karsch-Mizrachi I, Lipman DJ, Ostell J, Sayers EW (2016) GenBank. Nucleic Acids Res 44:D67-D72 . https://doi.org/10.1093/nar/gkv1276

13. Clementson LA, Wojtasiewicz B (2019) Dataset on the absorption characteristics of extracted phytoplankton pigments. Data Br 24:103875 . https://doi.org/10.1016/j.dib.2019.103875

14. Degryse J, Hulle M Van, Hird S (2017) The Analysis of Cyanotoxins, Including Microcystins, in Drinking and Surface Waters by Liquid Chromatography-Tandem Quadrupole Mass Spectrometry. 16 [APPLICATION NOTE]

15. Duperron S, Beniddir MA, Durand S, Longeon A, Duval C, Gros O, Bernard C, Bourguet-Kondracki M-L (2019) New benthic cyanobacteria from guadeloupe mangroves as producers of antimicrobials. Mar Drugs 18:16 . https://doi.org/10.3390/md18010016

16. Edgar R (2016) UCHIME2: improved chimera prediction for amplicon sequencing. bioRxiv 074252 . https://doi.org/10.1101/074252 
17. Herdman M, Rippka R (2017) Cyanobacterial phylogeny. November 1, 2021. http://cyanobact.000webhostapp.com/

18. Hoiczyk E, Baumeister W (1995) Envelope structure of four gliding filamentous cyanobacteria. J Bacteriol. 177(9):2387-2395. doi:10.1128/jb.177.9.2387-2395.1995

19. Izaguirre G, Taylor WD (2007) Geosmin and MIB events in a new reservoir in southern California. Water Sci Technol 55:9-14 . https://doi.org/10.2166/wst.2007.156

20. Jaskulska A, Mankiewicz-Boczek J (2020) Cyanophages specific to cyanobacteria from the genus Microcystis. Ecohydrol Hydrobiol 20:83-90 . https://doi.org/10.1016/j.ecohyd.2019.06.001

21. Jiang X, Ha C, Lee S, Kwon J, Cho H, Gorham T, Lee J (2019) Characterization of cyanophages in Lake Erie: Interaction mechanisms and structural damage of toxic cyanobacteria. Toxins (Basel) 11: . https://doi.org/10.3390/toxins11080444

22. Johansen JR, Mareš J, Pietrasiak N, Bohunická M, Zima J, Štenclová L, Hauer T (2017) Highly divergent 16S rRNA sequences in ribosomal operons of Scytonemahyalinum (Cyanobacteria). PLoS One 12:e0186393 . https://doi.org/10.1371/journal.pone.0186393

23. Juin C, Bonnet A, Nicolau E, Bérard J-B, Devillers R, Thiéry V, Cadoret J-P, Picot L (2015) UPLC-MSE profiling of phytoplankton metabolites: application to the Identification of pigments and structural analysis of metabolites in Porphyridiumpurpureum. Mar Drugs 13:2541-2558 . https://doi.org/10.3390/md13042541

24. Komárek J, Anagnostidis K (1995) Nomenclatural novelties in chroococcalean cyanoprokaryotes. Preslia 1995:15-23

25. Komárek J, Anagnostidis K (1998) Cyanoprokaryota 1.Teil: Chroococcales. - In: Ettl, H.; Gärtner, G.; Heynig, H. \& Mollenhauer, D. (eds): Süsswasserflora von Mitteleuropa, Band 19/1. Gustav Fischer Verlag, Stuttgart-Jena

26. Komárek J, Komárková J (2002) Review of the European Microcystis morphospecies (Cyanoprokaryotes) from nature. Czech Phycol 2:1-24 . https://doi.org/citeulike-article-id:13073212

27. Kruip J, Bald D, Boekema E, Rögner M (1994) Evidence for the existence of trimeric and monomeric Photosystem I complexes in thylakoid membranes from cyanobacteria. Photosynth Res 40:279-286 . https://doi.org/10.1007/BF00034777

28. Kuznetsov YG, Chang S-C, Credaroli A, McPherson A (2013) Unique Tail appendages of marine bacteriophages. Adv Microbiol 03:55-59 . https://doi.org/10.4236/aim.2013.36a007

29. Kuznetsov YG, Chang SC, Credaroli A, Martiny J, McPherson A (2012) An atomic force microscopy investigation of cyanophage structure. Micron 43:1336-1342 .

https://doi.org/10.1016/j.micron.2012.02.013

30. Kuznetsov YG, Martiny JBH, McPherson A (2010) Structural analysis of a Synechococcus myovirus S-CAM4 and infected cells by atomic force microscopy. J Gen Virol 91:3095-3104 . https://doi.org/10.1099/vir.0.025254-0

31. Kuznetsov YG, McPherson A (2011) Atomic Force Microscopy in imaging of viruses and virusinfected cells. Microbiol Mol Biol Rev 75:268-285 . https://doi.org/10.1128/mmbr.00041-10 
32. Li M, Zhu W, Gao L, Lu L (2013) Changes in extracellular polysaccharide content and morphology of Microcystisaeruginosa at different specific growth rates. J Appl Phycol 25:1023-1030 . https://doi.org/10.1007/s10811-012-9937-7

33. Lilledahl MB, Stokke BT (2015) Novel imaging technologies for characterization of microbial extracellular polysaccharides. Front Microbiol 6:1-12 . https://doi.org/10.3389/fmicb. 2015.00525

34. Lopes G, Clarinha D, Vasconcelos V (2020) Carotenoids from cyanobacteria: A biotechnological approach for the topical treatment of psoriasis. Microorganisms 8: . https://doi.org/10.3390/microorganisms8020302

35. Ludwig W (2004) ARB: a software environment for sequence data. Nucleic Acids Res 32:1363-1371 . https://doi.org/10.1093/nar/gkh293

36. Lyra C, Suomalainen S, Gugger M, Vezie C, Sundman P, Paulin L, Sivonen K (2001) Molecular characterization of planktic cyanobacteria of Anabaena, Aphanizomenon, Microcystis and Planktothrix genera. Int J Syst Evol Microbiol 51:513-526 . https://doi.org/10.1099/00207713-51-2513

37. Mai T, Johansen JR, Pietrasiak N, Bohunická M, Martin MP (2018) Revision of the Synechococcales (Cyanobacteria) through recognition of four families including Oculatellaceae fam. nov. and Trichocoleaceae fam. nov. and six new genera containing 14 species. Phytotaxa 365:1 . https://doi.org/10.11646/phytotaxa.365.1.1

38. Martin EL, Kokjohn TA (1999) Cyanophages. In: Encyclopedia of Virology. Elsevier, pp 324-332

39. Melekhin AV, Davydov DA, Borovichev EA, Shalygin SS, Konstantinova NA (2019) CRIS - service for input, storage and analysis of the biodiversity data of the cryptogams. Folia Cryptogam Est 56:99108 . https://doi.org/10.12697/fce.2019.56.10

40. Melekhin AV, Davydov DA, Shalygin SS, Borovichev EA (2013) Open information system on biodiversity cyanoprokaryotes and lichens CRIS (Cryptogamic Russian Information System). Bull MOIP 118:51-6

41. Mishra S, Stumpf RP, Schaeffer B, Werdell PJ, Loftin KA, Meredith A (2021) Evaluation of a satellitebased cyanobacteria bloom detection algorithm using field-measured microcystin data. Sci Total Environ 774:145462 . https://doi.org/10.1016/j.scitotenv.2021.145462

42. Molot LA, Watson SB, Creed IF, Trick CG, McCabe SK, Verschoor MJ, Sorichetti RJ, Powe C, Venkiteswaran JJ, Schiff SL (2014) A novel model for cyanobacteria bloom formation: the critical role of anoxia and ferrous iron. Freshw Biol 59:1323-1340 . https://doi.org/10.1111/fwb.12334

43. Moreira C, Ramos V, Azevedo J, Vasconcelos V (2014) Methods to detect cyanobacteria and their toxins in the environment. Appl Microbiol Biotechnol 98:8073-8082 . https://doi.org/10.1007/s00253-014-5951-9

44. Mozaffari K, Seger M, Dungan B, Hanson DT, Lammers PJ, Holguin FO (2019) Alterations in photosynthesis and energy reserves in Galdieriasulphuraria during corn stover hydrolysate supplementation. Bioresour Technol Reports 7:100269 . https://doi.org/10.1016/j.biteb.2019.100269 
45. Ouellette AJA, Handy SM, Wilhelm SW (2006) Toxic Microcystis is widespread in Lake Erie: PCR detection of toxin genes and molecular characterization of associated cyanobacterial communities. Microb Ecol 51:154-165 . https://doi.org/10.1007/s00248-004-0146-z

46. Price MN, Dehal PS, Arkin AP (2010) FastTree 2 - approximately Maximum-Likelihood trees for large alignments. PLoS One 5:e9490 . https://doi.org/10.1371/journal.pone.0009490

47. Pruesse E, Peplies J, Glöckner FO (2012) SINA: Accurate high-throughput multiple sequence alignment of ribosomal RNA genes. Bioinformatics 28:1823-1829 .

https://doi.org/10.1093/bioinformatics/bts252

48. Quast C, Pruesse E, Yilmaz P, Gerken J, Schweer T, Yarza P, Peplies J, Glöckner FO (2012) The SILVA ribosomal RNA gene database project: improved data processing and web-based tools. Nucleic Acids Res 41:D590-D596 . https://doi.org/10.1093/nar/gks1219

49. Schaeffer BA, Bailey SW, Conmy RN, Galvin M, Ignatius AR, Johnston JM, Keith DJ, Lunetta RS, Parmar R, Stumpf RP, Urquhart EA, Werdell PJ, Wolfe K (2018) Mobile device application for monitoring cyanobacteria harmful algal blooms using Sentinel-3 satellite Ocean and Land Colour Instruments. Environ Model Softw 109:93-103 . https://doi.org/10.1016/j.envsoft.2018.08.015

50. Schindelin J, Arganda-Carreras I, Frise E, Kaynig V, Longair M, Pietzsch T, Preibisch S, Rueden C, Saalfeld S, Schmid B, Tinevez J-Y, White DJ, Hartenstein V, Eliceiri K, Tomancak P, Cardona A (2012) Fiji: an open-source platform for biological-image analysis. Nat Methods 9:676-682 . https://doi.org/10.1038/nmeth.2019

51. Schuergers N, Wilde A (2015) Appendages of the cyanobacterial cell. Life 5:700-715 . https://doi.org/10.3390/life5010700

52. Smith JL, Schulz KL, Zimba P V., Boyer GL (2010) Possible mechanism for the foodweb transfer of covalently bound microcystins. Ecotoxicol Environ Saf 73:757-761. https://doi.org/10.1016/j.ecoenv.2009.12.003

53. Springstein BL, Nürnberg DJ, Weiss GL, Pilhofer M, Stucken K (2020) Structural determinants and their role in cyanobacterial morphogenesis. Life 10:1-33 . https://doi.org/10.3390/life10120355

54. Stanier (Cohen-Bazire) G (1988) [14] Fine structure of cyanobacteria. In: Methods in Enzymology. pp 157-172

55. Sullivan MB, Waterbury JB, Chisholm SW (2003) Cyanophages infecting the oceanic cyanobacterium Prochlorococcus. Nature 424:1047-1051 . https://doi.org/10.1038/nature01929

56. Sure S, Torriero AAJ, Gaur A, Li LH, Chen Y, Tripathi C, Adholeya A, Ackland ML, Kochar M (2015) Inquisition of Microcystisaeruginosa and Synechocystis nanowires: characterization and modelling. Antonie Van Leeuwenhoek 108:1213-1225 . https://doi.org/10.1007/s10482-015-0576-2

57. Tan X, Shu X, Duan Z, Parajuli K (2020) Two types of bound extracellular polysaccharides and their roles in shaping the size and tightness of Microcystis colonies. J Appl Phycol 32:255-262 . https://doi.org/10.1007/s10811-019-01937-z

58. Thirumurthy MA, Hitchcock A, Cereda A, Liu J, Chavez MS, Doss BL, Ros R, El-Naggar MY, Heap JT, Bibby TS, Jones AK (2020) Type IV pili-independent photocurrent production by the cyanobacterium 
Synechocystis sp. PCC 6803. Front Microbiol 11:1-11 . https://doi.org/10.3389/fmicb.2020.01344

59. Towns J, Cockerill T, Dahan M, Foster I, Gaither K, Grimshaw A, Hazlewood V, Lathrop S, Lifka D, Peterson GD, Roskies R, Scott JR, Wilkins-Diehr N (2014) XSEDE: accelerating scientific discovery. Comput Sci Eng 16:62-74 . https://doi.org/10.1109/MCSE.2014.80

60. Turland, N. J., J. H. Wiersema, F. R. Barrie, W. Greuter, D. L. Hawksworth, P. S. Herendeen, S. Knapp, W.H. Kusber, D.-Z. Li, K. Marhold, T. W. May, J. McNeill, A. M. Monro, J. Prado MJP and GFS (2018) International Code of Nomenclature for algae, fungi, and plants (Shenzhen Code). Koeltz

61. Vaara T (1982) The outermost surface structures in chroococcacean cyanobacteria. Can J Microbiol 28:929-941 . https://doi.org/10.1139/m82-140

62. Vaara T, Ranta H, Lounatmaa K, Korhonen TK (1984) Isolation and characterization of pili (fimbriae) from Synechocystis CB3. FEMS Microbiol Lett 21:329-334 . https://doi.org/10.1111/j.15746968.1984.tb00331.x

63. Vermaas WFJ, Timlin JA, Jones HDT, Sinclair MB, Nieman LT, Hamad SW, Melgaard DK, Haaland DM (2008) In vivo hyperspectral confocal fluorescence imaging to determine pigment localization and distribution in cyanobacterial cells. Proc Natl Acad Sci 105:4050-4055 . https://doi.org/10.1073/pnas.0708090105

64. Via CW, Glukhov E, Costa S, Zimba P V., Moeller PDR, Gerwick WH, Bertin MJ (2018) The metabolome of a cyanobacterial bloom visualized by MS/MS-based molecular networking reveals new neurotoxic smenamide analogs (C, D, and E). Front Chem 6:1-9 . https://doi.org/10.3389/fchem.2018.00316

65. Vítek P, Jehlička J, Ascaso C, Mašek V, Gómez-Silva B, Olivares H, Wierzchos J (2014) Distribution of scytonemin in endolithic microbial communities from halite crusts in the hyperarid zone of the Atacama desert, Chile. FEMS Microbiol Ecol 90:351-366 . https://doi.org/10.1111/1574-6941.12387

66. Watkins SC, Smith JR, Hayes PK, Watts JEM (2014) Characterisation of host growth after infection with a broad-range freshwater cyanopodophage. PLoS One 9:1-8 .

https://doi.org/10.1371/journal.pone.0087339

67. Weiss GL, Kieninger A-K, Maldener I, Forchhammer K, Pilhofer M (2019) Structure and function of a bacterial gap junction analog. Cell 178:374-384.e15 . https://doi.org/10.1016/j.cell.2019.05.055

68. Yeo BH, Gin KY-H (2013) Cyanophages infecting Anabaenacircinalis and Anabaenacylindrica in a tropical reservoir. Bacteriophage 3:e25571 . https://doi.org/10.4161/bact.25571

69. Yoshihara S, Geng XX, Okamoto S, Yura K, Murata T, Go M, Ohmori M, Ikeuchi M (2001) Mutational analysis of genes involved in pilus structure, motility and transformation competency in the unicellular motile cyanobacterium Synechocystis sp. PCC 6803. Plant Cell Physiol 42:63-73 . https://doi.org/10.1093/pcp/pce007

70. Zborowsky S, Lindell D (2019) Resistance in marine cyanobacteria differs against specialist and generalist cyanophages. Proc Natl Acad Sci USA 116:16899-16908. https://doi.org/10.1073/pnas.1906897116

\section{Figures}




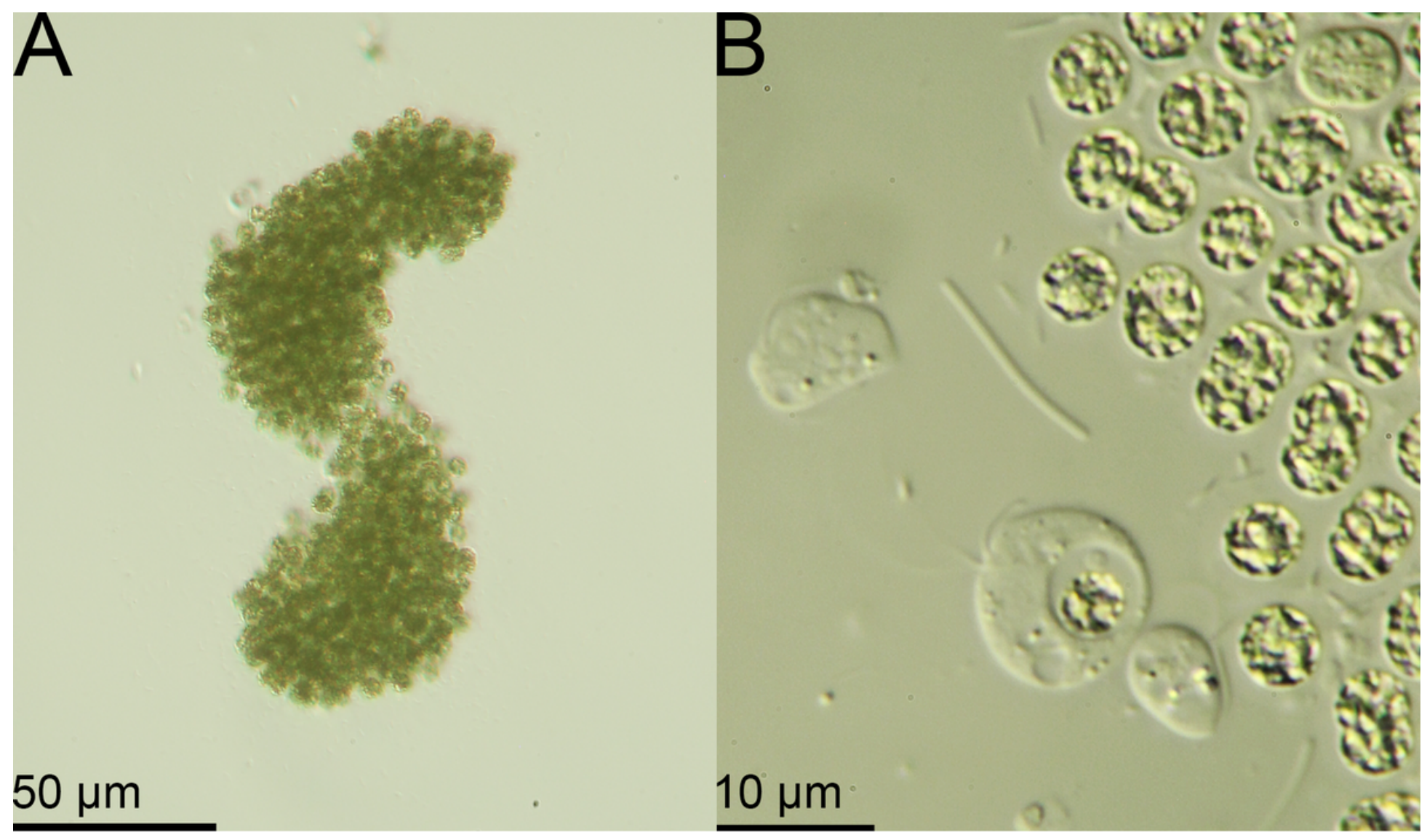

\section{Figure 1}

Different magnification images of the Microcystis sp. micro colony. A Bright field picture showing colony shape typical for Microcystis flos-aquae. B DIC image of the Microcystis colony. This image also shows ingestion of a single Microsystis cell by protozoan. Whether this cell would be digested is unknown. Notice dark black-green spots in the cells are aerotopes. 


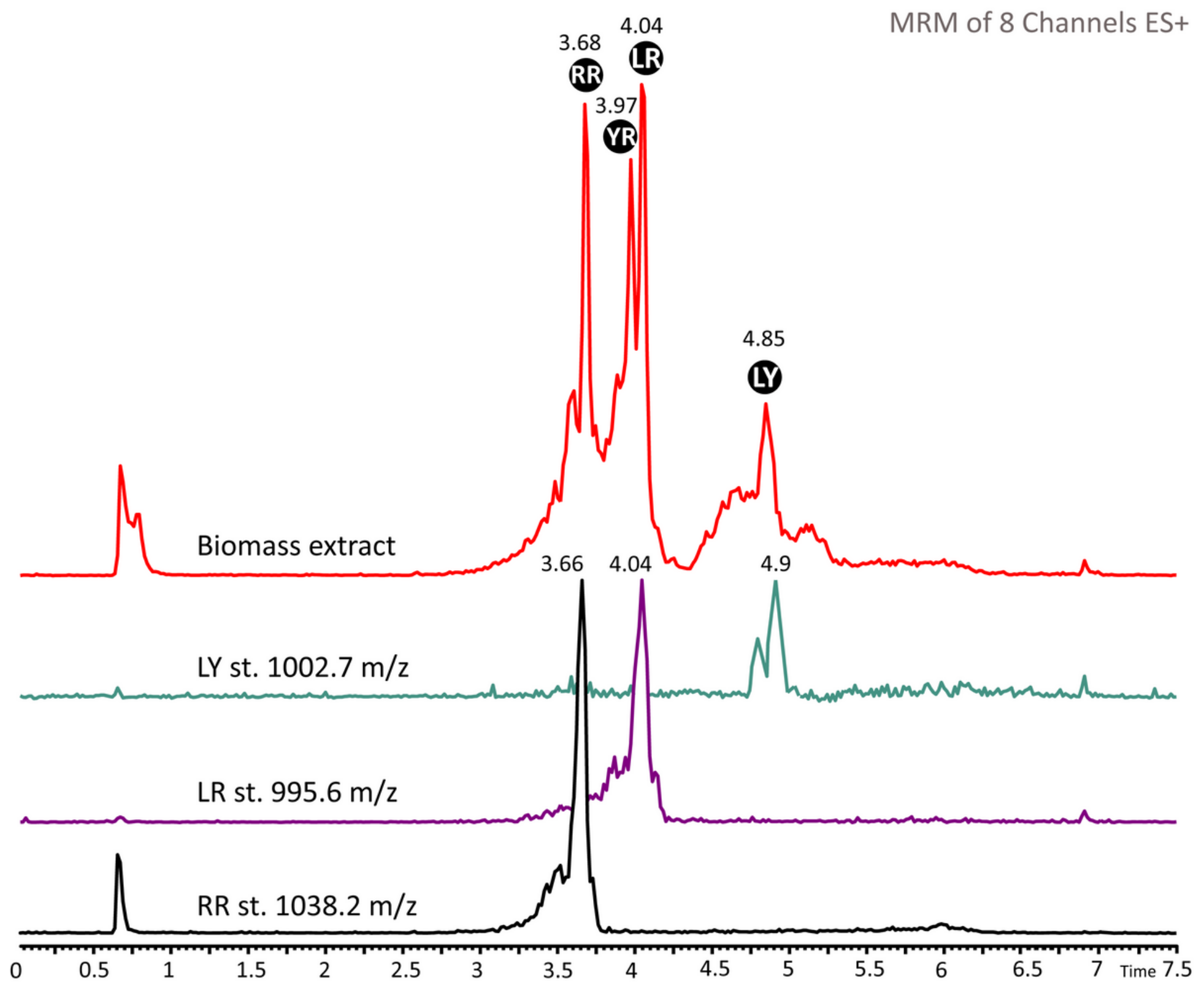

Figure 2

Overlay MRM chromatogram including standards for Microcystin-RR, -LR, -LY and the biomass extract. Note, biomass extract (upper chromatogram) contained Microcystin-RR, -LR, -LY for which standards (3 chromatograms on the bottom) were incorporated into analysis. Microcystin-YR was also detected (peak at 3.97), standard for which was not included. Retention times of the toxins in the extract and in the standards were almost identical. 


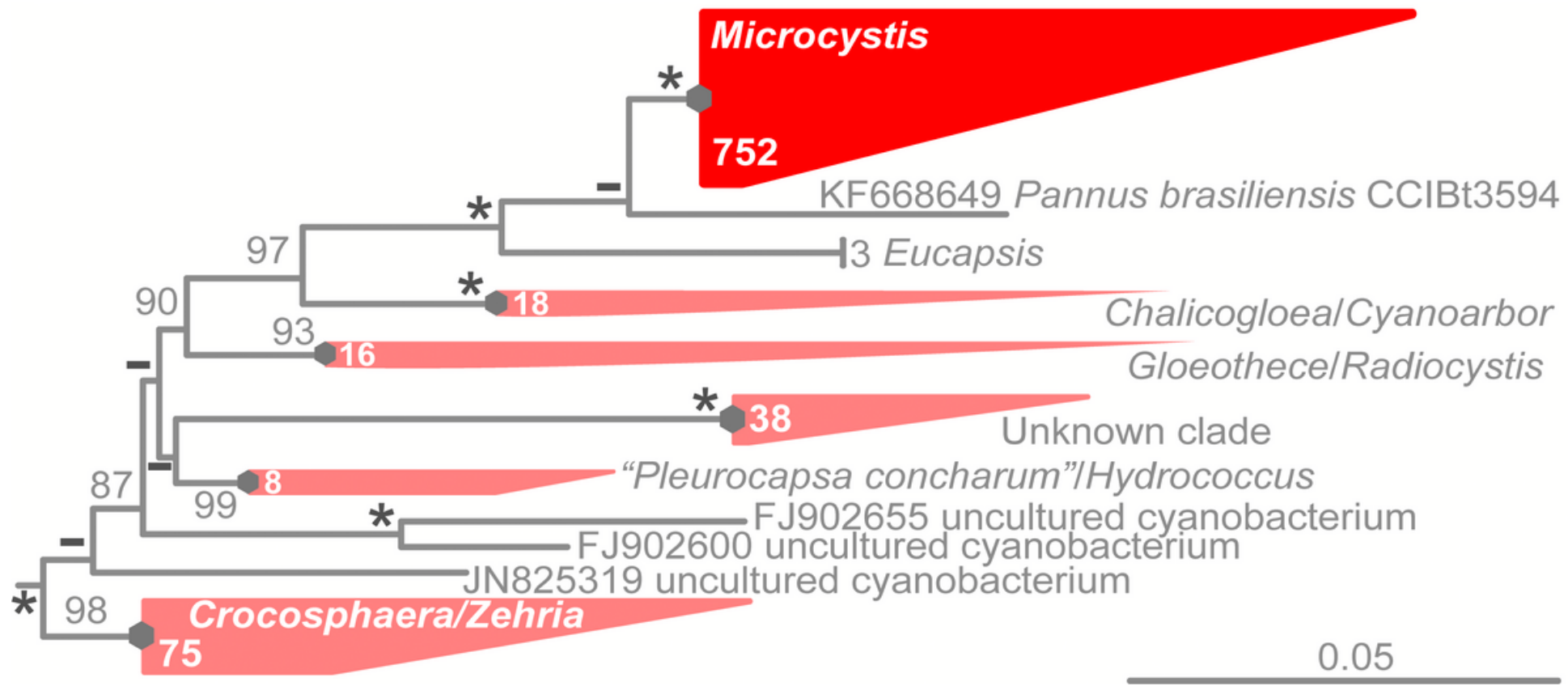

Figure 3

Part of the maximum likelihood 16S rRNA megaphylogeny showing phylogenetic position of the conventional Microcystis spp. (both sequences) in the red collapsed clade. Values in the collapsed clades are the numbers of taxa within each clades. Maximum support showed as "*", support less than $50 \%$ showed as "-". Full phylogeny is represented in Fig. S2. 


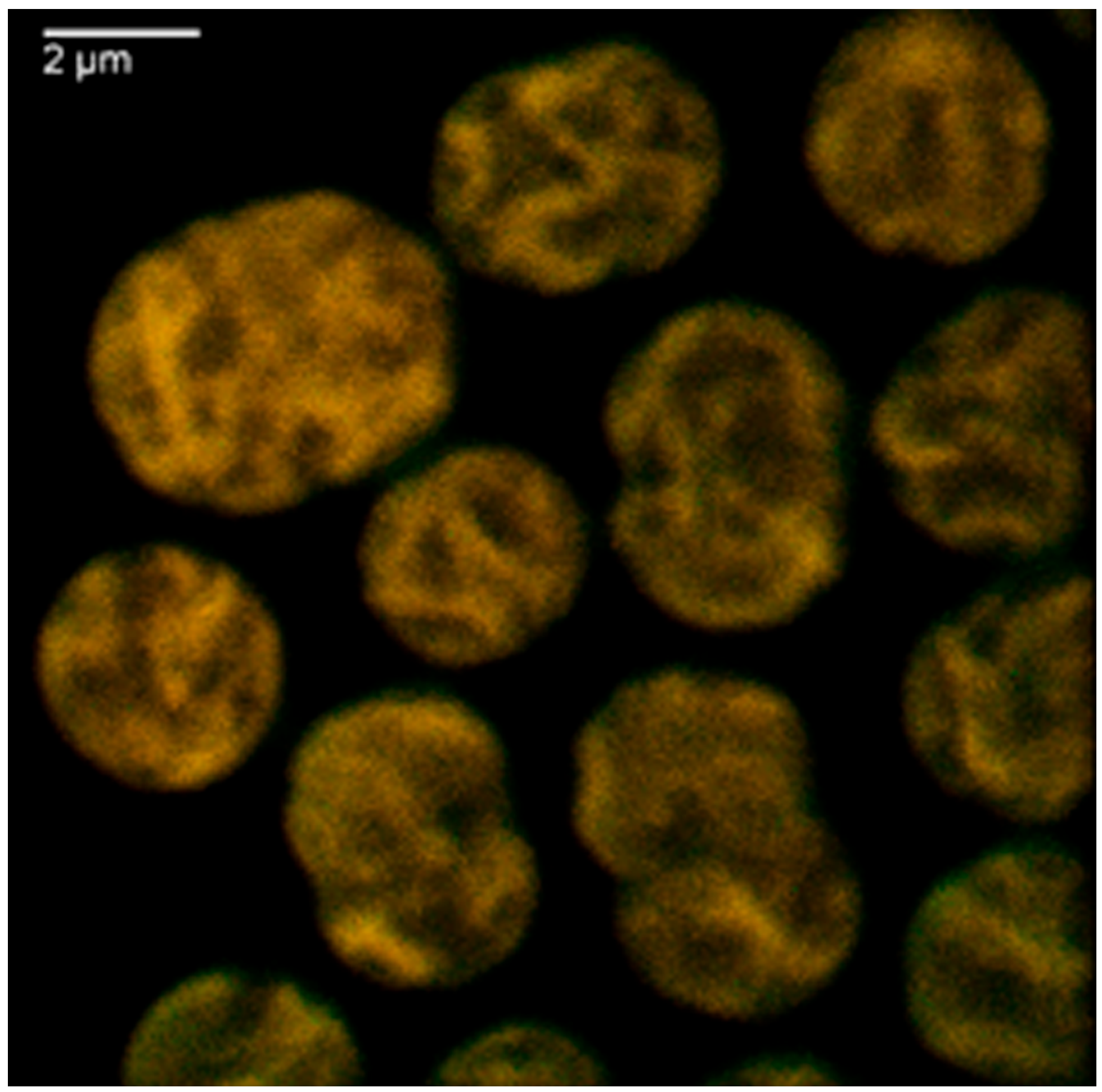

\section{Figure 4}

One focal plane confocal image of the cells of the Microcystis sp. Chlorophylls (red channel) and carotenoids (green channel) were mostly concatenated, giving yellow color shown on the picture. Clearly visible dark concave areas on the cell surfaces are aerotopes (no emission). 


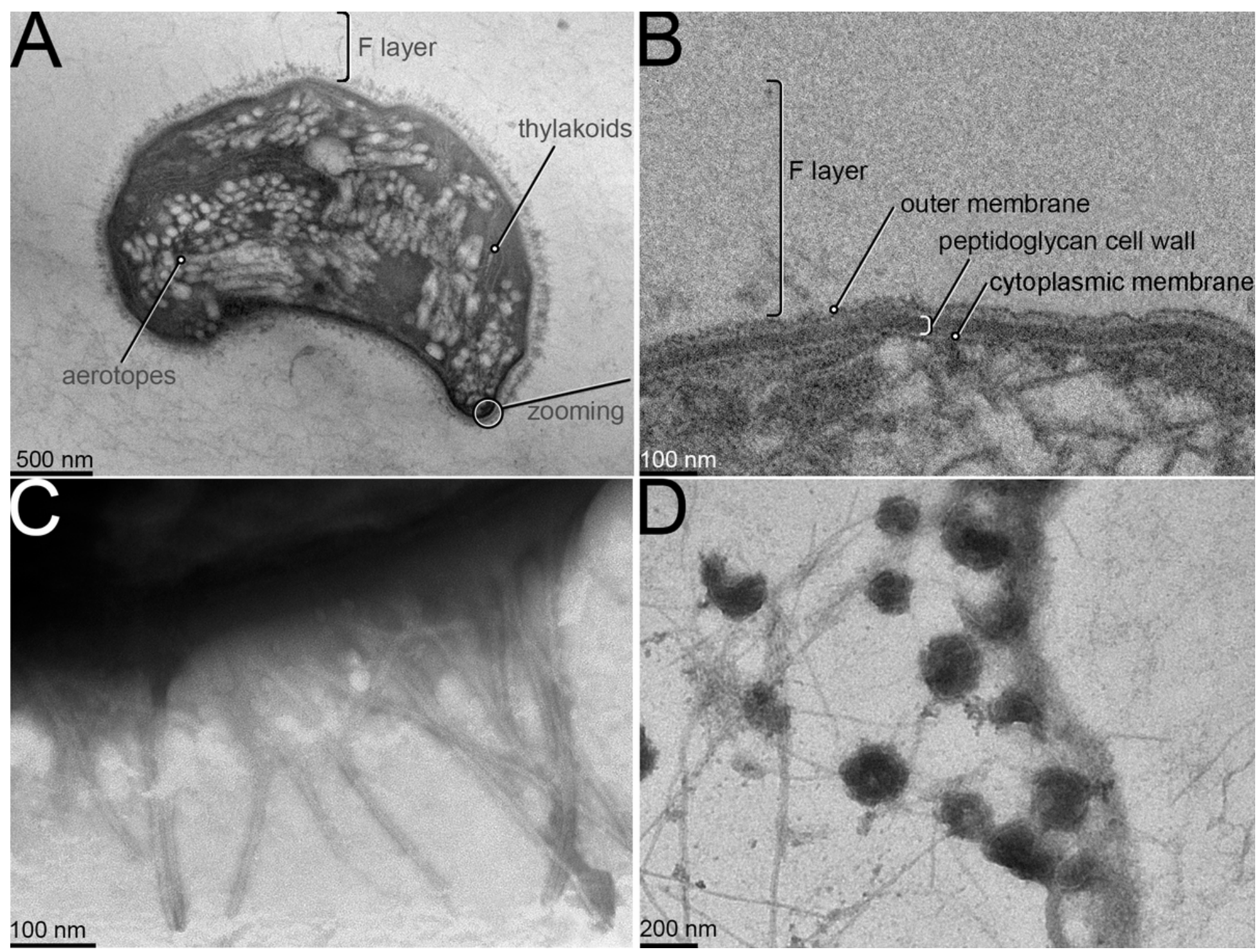

Figure 5

Various TEM images of Microcystis sp. cells and the cyanophages associated with it. A Thin section of the single cell. Note that the shape of the cell appeared to be irregular (not spherical or hemispherical), it is because of a particular plane of a thin section together with shrinkage during fixation, dehydration, and embedding. B Zoomed in portion showing edge of the cell including cytoplasmic membrane etc. $\mathbf{C}$ On the grid, negative staining TEM image of the pili-like structures. D On the grid negative staining TEM shows cyanophages. Cyanophages were found near the colonies but not inside the cells (Fig. S6A,B,C). 

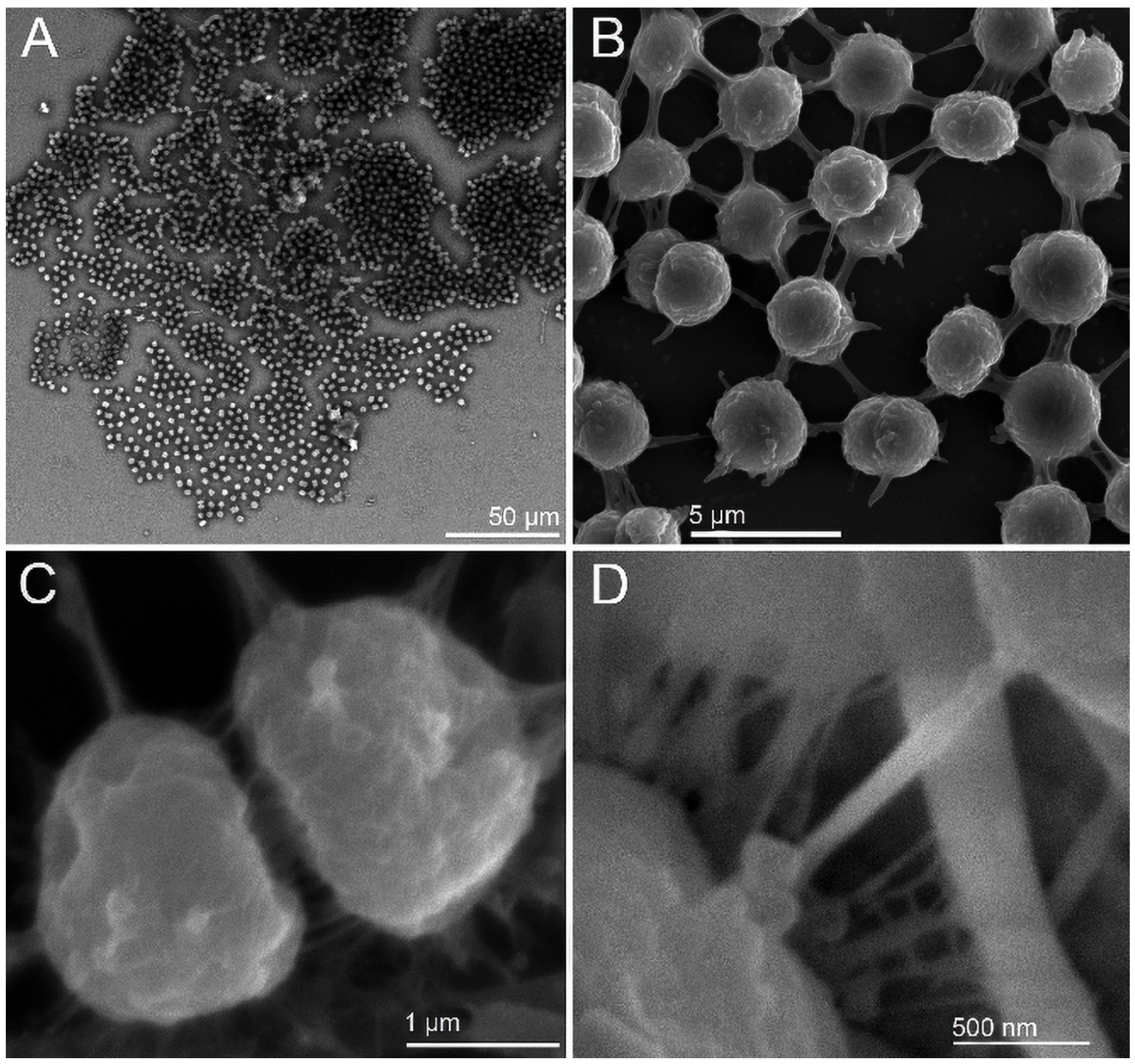

Figure 6

SEM of the cells of Microcystis sp. within the colony showing presence of a F-layer and pili-like structures. A Arrangement of a colony, note thinner colony layer on the bottom depicting edge of the colony, B Image showing pattern of the cells arrangement and strings of a dehydrated F-layer connecting the cells. C Recently divided cell, strings connecting newly divided cells are pili-like structures, D Close up look at pili-like structures (thinnest strings). 


\section{$2 \mu \mathrm{m}$}

$3.5 \mu \mathrm{m}$

h

E

i

h

$\mathrm{S}$

e

$n$

S

0

\section{Figure 7}

AFM height sensor image showing surface of the cells. Note bridges of the F-layer connecting the cells. 


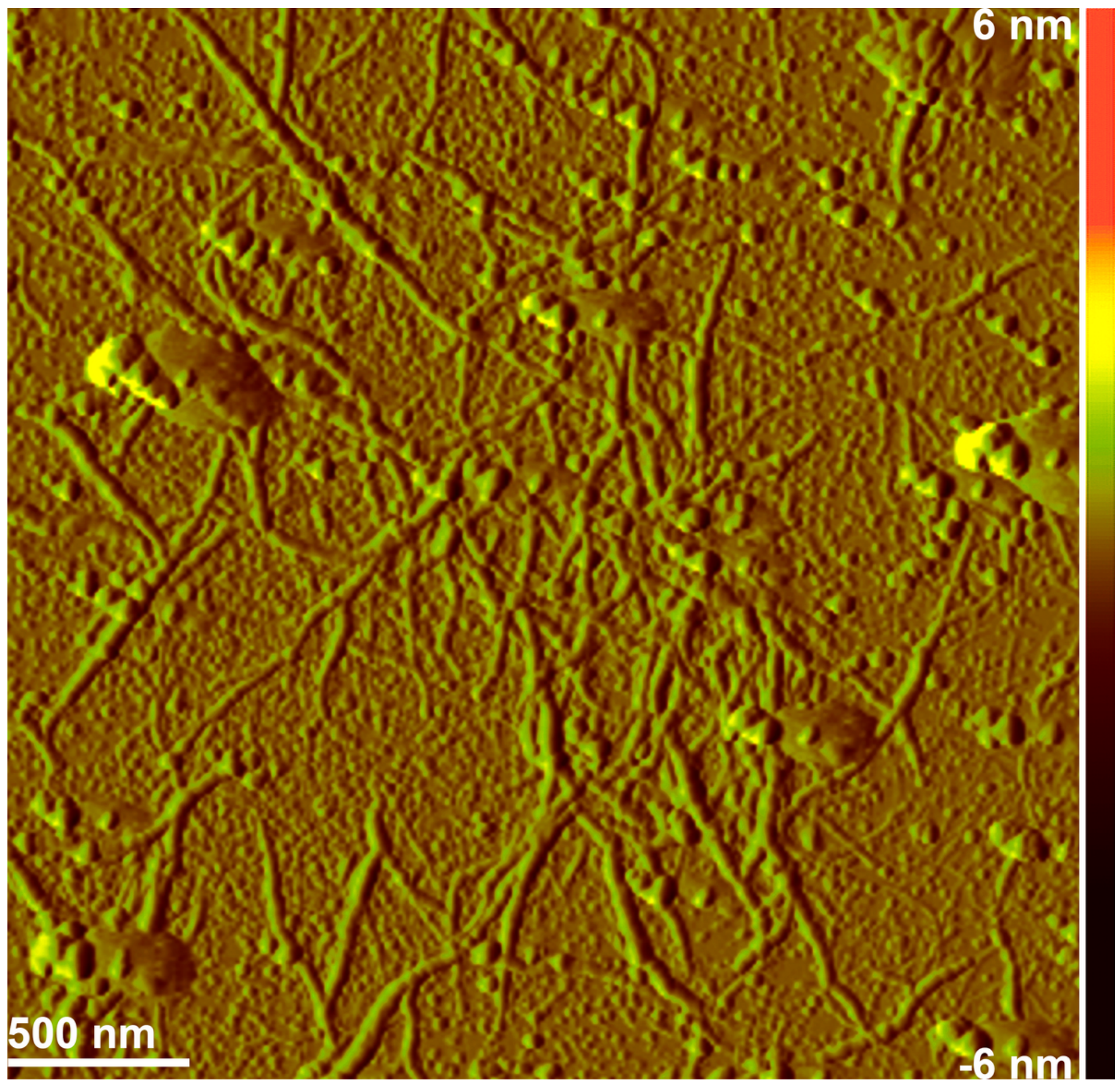

Figure 8

AFM amplitude error image demonstrating pili-like structures.

\section{Supplementary Files}

This is a list of supplementary files associated with this preprint. Click to download.

- FigS1.tif 
- Figs2.tif

- FigS3.tif

- Figs4.tif

- FigS5.tif

- FigS6.tif

- FigS7.tif

- Figs8.tif

- FigS9.tif

- FigS10.tif

- FigS11.tif

- SuppTables.docx 